\title{
A Day in the "Swamp": Understanding Discourse in the Online Counter-Jihad Nebula
}

\author{
Benjamin Lee
}

Author submitted version

\begin{abstract}
The counter jihad scene can be understood variously as a collection of parties, pundits and movements all linked by a common belief that the West is being subject to takeover by Muslims. In this paper, I seek to improve academic understanding of this collection of movements, parties and ideas by analysing the discourse presented by a collection of online advocates whom I describe as the counter jihad nebula. The findings suggest a need to at least partially re-evaluate the role of the nebula within the wider counter jihad scene as well as the relationship between the wider counter jihad scene and mainstream political discourse as expressed through various media outlets.
\end{abstract}

\section{Introduction}

The counter jihad scene has been an enigma to researchers, governments, citizens and, in all probability, its own supporters. Whilst traditional far-right movements predicated on xenophobia and racism are relatively easy to identify, the counter jihad scene emerged as something altogether more confusing. It has been referred to in one way or another frequently by researchers, in some cases as a mutated form of fascism, in others as a new and distinctive movement or scene in its own right. It has been noted as hateful and violent but has also appeared to champion of the rights of sexual and religious minorities in some cases, as well as claiming to be a staunch defender of the right to free speech. In essence, the counter jihad 
scene consists of a loose collection of parties, organisations and various associated pundits and talking heads united by their belief that they are witnessing an attempted Islamic takeover of the West. In this paper I attempt to further academic and policy understanding of the counter jihad scene as a whole by examining in detail a much referenced but seldom defined online wing described here as the counter jihad nebula (CJN). The description nebula is chosen evoke the indistinct character of the online wing of the counter jihad scene. There are no formal qualifications for membership, no barriers to entry and no centralised editorial control. This group of websites can be considered part of the counter jihad scene only by their shared ideas and sentiments; nevertheless, they have seemingly together formed an important component of the wider scene. Specifically, I aim to partially map and analyse a selection of sites within the CJN with the aim of developing a more detailed understanding of how the counter jihad narrative permeates through online networks.

To accomplish this, I first set out to synthesise briefly existing understandings of the wider counter jihad scene. Following this, I attempt to give a brief overview of counter jihad discourse as recorded by other accounts. I then go on to develop the position that online presences are a key element within the counter jihad scene that a distinctive counter jihad nebula exists, and highlight some contrasting theories of how such groups manifest online. I then outline the methods used and the findings of the analysis, specifically concentrating on the ambiguous relationship between the $\mathrm{CJN}$ and other, more mainstream, media outlets.

\section{Conceptions of the counter jihad scene}

Previous work has not addressed the idea of an online CJN specifically. Instead, it has frequently referenced the importance of online resources to a wider counter jihad ideology or movement. Even this is shadowy and difficult to define. Goodwin offers an interesting description of the composite parts of what he terms the "counter-Jihad scene": 
"Within an amorphous network of think-tanks, bloggers and activists, the counterJihad scene incorporates the 'defence leagues' in Australia, Denmark, England, Finland, Norway, Poland, Scotland, Serbia and Sweden, groups such as Pro-Cologne and the Citizens' Movement Pax Europa in Germany, Generation Identity in France, the 'Stop the Islamization' networks in Europe and the United States, the American Freedom Defense Initiative and the International Civil Liberties Alliance." 1

This broad interpretation is reflected in the work of other writers who have addressed specific components of the scene. Counter jihad inspired terrorism has stimulated much discussion. In his analysis of "lone wolf" terrorism Feldman refers the emergence of a "new far right" centred on prejudice against Muslims. ${ }^{2}$ In contrast, others have analysed anti-Muslim thought as a literary genre. ${ }^{3}$ Similarly, writers such as Gavan Titley, Liz Fekete, Paul Jackson, Jacob Ravndal, Toby Archer and Mattias Gardell have explored the relationships between the ideology expressed by counter-jihad and the murders perpetrated by Anders Behring Brievik. ${ }^{4}$ For example, Jackson analysed the writings of prominent counter jihad blogger Fjordman (AKA Peder Jennings) as reproduced in the Brievik manifesto. ${ }^{5}$ However, other analyses of Brievik have played down the significance of counter jihad bloggers, suggesting that Brievik's prejudices predated the establishment of many blogs (although his views were likely subsequently strengthened by material he found online). ${ }^{6}$ Others have arrived at a wider counter jihad movement through the emergence of prominent street movements based such as the English Defence League (EDL). ${ }^{7}$ Joel Busher, for example, undertook extensive ethnographic study of the UK-based street movement, highlighting the discourse of members and drawing out the role of anti-Muslim thought within the wider movement. ${ }^{8}$ Also flowing from analysis of the EDL, Melagrou-Hitchens and Brun identify "Europe's Counter-Jihad Movement". 9 The counter jihad scene has also been used as a way of illustrating the emergence of a European Public Sphere, where it was described as a "loose global 
fraternity". ${ }^{10}$ Outside of academic debate, the counter jihad scene has also been identified in work by issue groups such as Hope Not Hate's report on the counter jihad movement, as well as journalistic accounts such as Toby Archer's contribution to Foreign Policy which inspired the title of this paper. ${ }^{11}$

\section{Islamification and the decline of the West}

The counter jihad scene has been difficult for scholars to categorise. Some have seen it as representing something essentially novel and different from what has gone before, stressing that the narrative of the counter jihad is different from that of traditional far right parties. For Melagrou-Hitchens and Brun what they describe as the European Counter Jihad Movement is a distinctive "identifiable pan-European far-right movement". ${ }^{12}$ Along with Goodwin, Melagrou-Hitchens and Brun differentiate the counter jihad from traditional anti-immigrant and ethnic nationalist groups on the grounds that they do not attempt to develop a wider ideological programme and instead focus only on their opposition to Islam. ${ }^{13}$ Jackson and Feldman place the EDL within what they consider the 'new far right', highlighting the reconfiguration of narratives to avoid unfashionable racial and anti-Semitism whilst still reflecting the politics of 'hate'. ${ }^{14}$ Other accounts also see the incorporation of anti-Islamic themes as being an element in the reconfiguration of traditional far-right narratives, with parties replacing anti-Semitism and nationalism with an anti-Islamic narrative based on Judeo-Christian values and a sense of shared Europe-wide culture. ${ }^{15}$ A similar position is expressed by Kundnani for whom the counter jihad is "compatible" with older interpretations of neo-Nazism in which the predicted race war has been replaced with a cultural one. ${ }^{16}$ As both Matt Goodwin and Joel Busher note, the counter jihad scene is embryonic and the extent to which it either develops its own political parties or is able to influence others, in particular those who currently occupy the far right spectrum, remains to be seen. ${ }^{17}$ Equally, the counter 
jihad scene cannot be viewed as a monolith, it is instead composed of a myriad of different ideas and people with indistinct boundaries. ${ }^{18}$

Loosely speaking, for the counter jihad scene, Europe and the US are under threat from an aggressive and politicised Islamic world that is attempting to take over Europe through a process of "Islamification" with the eventual aim of imposing Sharia law. In this process the threat is characterised by the perceived removal of Christian or Jewish symbols, the imposition of Islamic traditions and the creation of no-go areas for non-Muslims. ${ }^{19}$ The construction of mosques in particular is seen as continued reinforcement of the separation of the Muslim population from the wider populous. ${ }^{20}$ As strong as the threatening practices of Muslims in descriptions of the counter jihad are images of a powerless Europe in decline and sliding into decadence, unable to resist Islamic take over. ${ }^{21}$ The idea that European culture in particular is in a state of decline, while a spiritually vigorous East represented by Islam is in the ascendancy in civil society, is a common sentiment in some circles. Carr points out that the argument has found favour with prominent conservative commentators such as Melanie Philips and Mark Steyn. ${ }^{22}$ In 2004, the historian Niall Ferguson contributed an article to the New York Times in which he speculated about "A creeping Islamicization of a decadent Christendom ". ${ }^{23}$ Carr also notes the difference between sarcastic references to Islamic immigration and demographic shifts in Europe and belief in a purposive political project, i.e. conspiracy. ${ }^{24}$ In some accounts, belief in the conspiracy is a dividing line between a hard core of counter jihad activists and a more mainstream conservative right wing outside the boundaries of the counter jihad scene. ${ }^{25}$ Equally, for Zúquete there remains a divide between rational and critical engagement with Islam and irrational, "fear-laden" accounts. ${ }^{26}$ The starting point for understanding counter jihad discourse comes from its understanding of cultural and political identity. Accounts of extreme right ideology have highlighted the distance that many groups have placed between themselves and discourse based on race and 
biology. ${ }^{27}$ Where traditional fascist narratives may have been based on pseudo-scientific understandings of identity based on genetics or heritage, the question of identity has now been transferred very much to the sphere of a wider cultural politics. ${ }^{28}$ However, it is worth noting how authentic many of these transitions have been, with some arguing that these changes are merely superficial. ${ }^{29}$ Melagrou-Hitchens and Brun argue in their interpretation that the counter jihad movement is based on what they describe as a form of cultural nationalism in which nations and citizens are defined by a shared history, culture and values. ${ }^{30}$ Furthermore, the removal of narrow national and ethnic definitions of identity has enabled the counter jihad scene to take on a more international character with organisations from different countries co-operating and working together. ${ }^{31}$ Revised discourses very often frame identity at a European or "Western" level, suggesting that the far-right may be moving to some degree beyond a simple nationalist interpretation of world events and acquiring a more international perspective. ${ }^{32}$ It is perhaps this factor more than any other that distinguishes the counter jihad scene from other parts of the populist right. ${ }^{33}$ In addition, religion is often invoked as an identity shorthand for the "West". It is important to note that this does not always pertain to high levels of religiosity. Breivik, for instance, presented himself as a "cultural Christian" as opposed to being personally religious in his manifesto. ${ }^{34}$ This position of cultural nationalism leads to a number of other seemingly incongruous positions for the counter jihad scene including fervent support for human rights, tolerance and free speech in particular in comparisons to counter jihad presentations of illiberal Sharia law. ${ }^{35}$ In addition, possibly as a result of political opportunism, the counter jihad scene is often fiercely pro-Israel. ${ }^{36}$

Stemming from the positioning of the counter jihad scene as the defenders of "Western civilisation" is the extent to which they have seized on Muslims and Islam as the cultural other, and the degree to which Muslims are felt to present both an external and internal threat 
to this identity. For writers that see the counter jihad as an essentially repackaged version of the fascist race-war narrative, the position of Muslims in the counter jihad is often seen as being analogous to that of the Jewish or Black people in a traditional fascist narrative. ${ }^{37}$ Some writers describe Muslims as being portrayed as "theological automatons" in the counter jihad discourse, unified in thought and deed; effectively Muslims are seen as a homogenised and hostile mass. ${ }^{38}$ Islam as a whole is presented as not just a religion but a totalitarian political force, and any action that can be linked to this monolithic understanding of "Islam" is deployed as evidence in support of hostile intent or action. ${ }^{39}$ Fekete presents this practice as the "essentialising" of Islam: "It is depicted as the same across centuries, backward and barbaric since the time of the Prophet, unable and unwilling to adapt to different historical and cultural settings." 40

The choice of Muslims as the main antagonists by counter jihad activists has been presented by some as political opportunism and in some cases as a result of a strategic abandonment of anti-Semitic themes. ${ }^{41}$ Exacerbated by the $9 / 11$ and 7/7 attacks, and incidents such as the murder of Lee Rigby, the position of the Muslim community in Britain and elsewhere has come under intense public scrutiny which has been accompanied by increased reporting of discrimination experiences. ${ }^{42}$ For both Fekete and Kundnani, the governmental security response to these issues has also been a driving factor in both legitimising the views held by counter jihad scene and in overlooking the threat presented by them. ${ }^{43}$ The popular press has also been seen as further legitimising anti-Muslim views. ${ }^{44}$ Treadwell and Garland's case studies of young men involved in the EDL also point to the connection between hostility to Muslims and the perception of socio-economic inequality by EDL members. ${ }^{45}$ Muslims, in this narrative, serve as scapegoats for a variety of broader perceived problems such as housing and other government services, a situation further exacerbated, Treadwell and Garland argue, by media coverage. ${ }^{46}$ There is also a degree of variation in the extent to which 
European Muslims are seen as engaged in Islamisation. Some groups within the counter jihad scene acknowledge the existence of moderates. ${ }^{47}$ Others, however, point to the concept of "Taqiyya", a practice that is seen as allowing a Muslim to deny their faith if it is to the overall benefit of Islam. This, they argue, could mean the entire European Muslim population was engaged in the same plot. ${ }^{48}$

Having established an understanding of "us" based on shared cultural values, and a "them" based on a homogenised and hostile Muslim world bent on conquering the West from within, the counter jihad scene seeks to explain how this can be allowed. On one level the apparent permissiveness of Western societies in allowing Muslims to remain can be interpreted as political elites' weakness or incompetence. In some interpretations, failure to act to prevent Islamisation has resulted from political cowardice or greed. ${ }^{49}$ Very often the blame for Islamisation is allocated to multiculturalists, who are seen as enabling the continued threat to values and identity presented by Islamisation. ${ }^{50}$ One favoured term for summarising and dismissing progressives or multiculturalists is "cultural Marxists". ${ }^{1}$

On a deeper level, the failure of political and cultural leadership to prevent Islamisation is interpreted as sinister. The counter jihad scene has what Kundnani argues is a "structural need" for a conspiracy theory in order to explain the apparent political failure. ${ }^{52}$ One (perhaps the predominant) master template for this conspiracy was set down in a book published in 2005 by an Egyptian born, British citizen living in Switzerland - Giselle Litmann - known under her pen name as Bat'Yeor. ${ }^{53}$ Focusing on a Franco-Arab alliance, Yeor argues that the French and the European Community embraced the Arab world in attempt to create a unified foreign policy power capable of balancing the United States. ${ }^{54}$ She also attempts to link French collaborators and Nazi sympathisers to this decision, suggesting anti-Semitism as a further unifying factor. The end point of Yeor's analysis is the belief that Europe exists in a state of "Dhimmitude", that is as states subservient to Muslim rulers characterised by 
"passive submission to intellectual censorship, insecurity, internal violence, and even terrorism". Unsurprisingly, Yeor's approach has been criticised and her academic qualifications questioned. ${ }^{55}$

\section{Waging the counter jihad online}

Organisationally, the web is seen as playing a facilitating role within the counter jihad scene, allowing various components to share information and coordinate work. ${ }^{56}$ Toby Archer in particular argues that without the web, the transatlantic counter jihad would not have come about. ${ }^{57}$ In further investigation Meleagrou-Hitchens and Brun maintain that the use of the internet is part of a conscious strategy within the counter jihad scene to adopt a distributed organisational model to limit the risks of legal action, unofficial political action from the left and the hostility of militant Muslims. ${ }^{58}$ They further point out that a decentralised organisational structure lends itself to consensus decision making and limits the risk of the infighting seemingly endemic in many fringe political groups. Kundnani identifies two key areas in which the web has played a role in the formulation of the counter jihad scene. ${ }^{59} \mathrm{He}$ identifies the role played by existing online connections between football firms in the early days of the EDL as well as the role played by social media in drawing in young people. He also acknowledges the influence of "far-right websites" on Breivik's manifesto. ${ }^{60}$ Immediately following the attacks of September the $11^{\text {th }} 2001$, the internet was reported as being a conduit for anti-Islamic sentiment in the form of comments directed towards Muslim websites. ${ }^{61}$ As far back as 2006, online commentators such as Fjordman were identified as playing a key role in forwarding the nascent counter jihad ideology. ${ }^{62}$ Following the 2011 Breivik killings, greater attention was paid to the counter jihad scene and their online inspiration. The Guardian analysed the web pages linked to by Breivik's manifesto. Amongst the morass of sites uncovered, a cluster of 14 nodes were labelled as "counter-jihad". ${ }^{63}$ Paul Jackson suggests that the website Gates of Vienna is a key space for the reproduction of the 
writings of Fjordman. ${ }^{64}$ The influence of anti-Muslim thought online has emerged as a common theme in the analyses of Breivik's manifesto. ${ }^{65}$

Further work has attempted to clarify counter jihad thought in various online venues. In January 2013 the Amsterdam-based Digital Methods Initiative undertook a four-day workshop and 'data sprint', using a variety of tools and approaches to learn more about counter jihad activities online. ${ }^{66}$ The initiative looked mainly at the use of social media by counter jihad activists, including studies looking at the English Defence League's use of Facebook. ${ }^{67}$ Again, looking at data scraped from social media, the group found some evidence of overlapping memberships of pro-Israeli and counter jihad spaces on both Facebook and Twitter, supporting to some extent the theoretical connection between the two ideas. ${ }^{68}$ A further analysis harvested data from Amazon, analysing passages highlighted by readers of counter jihad literature to set out a broader conception of counter jihad discourses as understood by audiences rather than authors. Users were found to most commonly highlight passages implying that Islam was violent. ${ }^{69}$

That the web should feature so heavily in accounts of the counter jihad fits with a broader understanding of the role of the web in enabling the bringing together of minority viewpoints and reducing legal risks. ${ }^{70}$ In addition, the web can provide groups with an opportunity to circumvent hostile gatekeepers in the mainstream media. ${ }^{71}$ The web grants the user a huge degree of receiver control. Where media such as television and newspapers are relatively scarce, linear and fixed, the web offers almost limitless opportunities for users to choose content and sources that reflect their own interests. ${ }^{72}$ The ability to filter content and coalesce with like-minded people has been seen by some as of great benefit to consumers and by others as having possibly negative effects for democracy. ${ }^{73}$ The low barriers to entry into the online sphere have been singled out by writers such as Nathan Lean as allowing the counter jihad scene to develop from a few local pockets of anti-Muslim thought to a broader 
international movement. ${ }^{74}$ Sunstein argues that within like-minded communities members are likely to be exposed only to one-sided arguments, be keen to match their views to others within the same group, and to develop extreme arguments as their initial viewpoints are continually confirmed. ${ }^{75}$ The result, he argues, is the development of polarised communities with a predilection for the most extreme viewpoints. For the CJN we can predict that the web allows for the continuation of the shared discourse of Islamic takeover in the West that is not shared (to the same extent) by the mass media. Beyond this, we might expect that the counter jihad would conform to the pattern of an "echo chamber" as set out by Sunstein that is avoiding connections with sources that either disagree or challenge the shared discourse of Islamic takeover ${ }^{76}$ Certainly in the case of Breivik, the use of online space provided him with an uncontested reality in which his views were able to develop unchallenged. ${ }^{77}$

There is also, however, a strong thread in the academic counter jihad literature that suggests advocates of the counter jihad world-view have also been influenced by mainstream narratives originating from government and mainstream media. Kundnani makes the case that the rise of counter jihadism has been enabled by a "blind spot" in mainstream security narratives brought about by the "War on Terror" ${ }^{78}$ In this climate, he argues, security narratives have come to focus increasingly on values and identity with the effect of tacitly endorsing the conceptions of values and identity put forward in counter jihad narratives as well as limiting the ability or willingness of state institutions to counter or censure right-wing extremist narratives. In other words:

“...the uncomfortable truth is that the central plank of a terrorist's [Breivik] narrative is shared by the heads of Western European governments. " 79

Kundnani's position closely echoes that of Fekete's earlier concerns over the impact of the post $9 / 11$ shift to what she describes as "the security state". ${ }^{80}$ Archer also draws attention to what he sees as close ties between anti-Muslim blogs and 'right of centre' media in the US. ${ }^{81}$ 
Equally, we can look at mainstream conservative engagement with the Eurabia conspiracy and the concept of Islamisation, as well as work looking at the influences on Breivik in order to further support the claim that the CJN will have closer connections to mainstream narratives and thought than its apparent pariah status might imply. ${ }^{82}$ If it is the case that mainstream discourse has lent the counter jihad ideology greater legitimacy, then we might expect to find greater connection to mainstream and government sites within in the online counter jihad.

\section{Mapping and understanding the counter jihad nebula}

Testing the two possible theses, of a closed echo chamber and a more open CJN, was a twostage process. Initially, the researcher mapped websites that could be considered to belong to the CJN. This was accomplished through the use of two related computer programmes: VOSON and NODEXL. VOSON is a tool for collecting hyperlinks and the relationships between websites. NODEXL is a plugin for Microsoft Excel which allows the resulting network data to be imported and displayed.

This process is the basis of hyperlink network analysis, which in turn applies methods from social network analysis to the relationships between websites. Social network analysis is centred on understanding what Scott describes as "relational data" which captures connections between actors rather than the attributes of actors themselves (attribute data). ${ }^{83}$ In this instance, however, the structure of the counter jihad nebula is of less importance to understanding the composition and resultant discourse within CJN than the attributes of those nodes within it, i.e. the extent to which they share in the wider counter jihad discourse. The aim of this study is not to map the structure of the entirety, or even most, of the counter jihad nebula, but to establish the extent to which counter jihad discourse was reproduced across different nodes connected to already well-known central nodes in the network. 
The hyperlink network analysis was based on a seed set of five sites identified in existing academic literature: Gates of Vienna, Brussels Journal, Jihad Watch (Robert Spencer), Atlas Shrugs (Pamela Geller) and Politically Incorrect. The group of seed sites was consciously chosen to be small so as to ensure that the content within the resulting network and content could be realistically analysed. Each of these sites was used as a seed site in a web crawl performed through VOSON and analysed using the NodeXL template. The crawl was set to collect outgoing links only, to a maximum of 1000 and a page depth of 50 . The crawl was launched and completed on the $25^{\text {th }}$ of June 2014. The resulting network contained 791 nodes joined by 843 links. In order to identify the relevant components, this network was further reduced to include only the nodes from the seed set and those that retained more than two links from the original seed set. This was done to ensure that nodes included in the analysis were considered valid by a minimum of two of the seed sites. This resulted in a set of 46 websites connected to by two or more of the seed sites. This list was further reduced by excluding sites not written in English as being difficult for the (English-speaking) researcher to analyse accurately.

The resulting network was then used as the basis for a qualitative inquiry into the nature of the sites included within the resulting network with the aim of determining the extent to which the discourses present on identified sites supported, were unrelated to, or contradicted the discourse of the counter jihad scene summarised above. Discourse, in this instance, represents more than superficial story-telling; instead it represents a broader model of the world ${ }^{84}$ Where sites linked to a specific item of content such as a video or a single story, this was taken as the text corresponding to that node. Where sites linked to a home page of a site that did not appear to regularly update, the home page was taken as the basis of the analysis. Where a site did update, for example a blog or a news site, and where site design made this possible, then the three most recent stories (from the $25^{\text {th }}$ of June) were taken as the texts for 
analysis. ${ }^{85}$ This approach aims to capture the content most relevant for the sites inclusion in the network at the time of the crawl.

\section{Structure of the counter jihad nebula}

We can make a number of readily apparent observations looking at the resulting networks identified through the web crawl. Of the five seed sites only one site - Jihad Watch - failed to produce any outgoing links. Even a cursory examination of Jihad Watch shows that the page does include hyperlinks. The failure of Jihad Watch to crawl may indicate a failure with the VOSON software or, more likely, that the site contains features that make it difficult to crawl using tools such as VOSON. ${ }^{86}$

\section{FIGURE ONE PLEASE}

Beyond the seed sites a further 46 sites have been identified. In most examples links were directed to home pages rather than specific articles; in a minority, links pointed to specific items of content embedded in larger sites. As well as the five sites included in the initial seed set, there are a number of additional sites that might easily be included within an explicitly defined counter jihad nebula, including The Religion of Peace. More of a surprise has been the inclusion of both alternative and mainstream media sites including the $B B C$, Wall Street Journal, Bild and The Daily Mail. In most cases these nodes are included as they feature a link to a specific story, although a number of additional media organisations have been included in the network without linked to specific stories, representing a more general endorsement by the linker. These are difficult to characterise as mainstream and seem to represent a more divergent interpretation of right wing politics. Breibart, National Review and Hotair all comfortably fit the typology of partisan news platforms. In addition, the network also includes a large collection of personal blogs, many of which have been abandoned and a number of links to social media or Web 2.0 sites, including Twitter, Facebook and Wikipedia. 


\section{FIGURE TWO PLEASE}

\section{Discourse in the counter jihad nebula}

Within the seed sites the discourse closely matches the themes developed by existing literature. In the available corpus, explicit references to the identity of authors were relatively scarce, perhaps suggesting that much of this remains implicit. However, on a number of occasions it was clear that authors had a fairly general understanding that they were writing in the defence of the "West". For example, Pamela Geller republished two columns she had written for the website World Net Daily under the title "Defending the West".

Muslims are treated akin to being a homogeneous mass as predicted. In a response to a Mail Online article, Robert Spencer rubbishes the claim made in the article that poverty and austerity are driving rising extremism, arguing that Islam is the defining factor. ${ }^{87}$ Geller repeats this point in an article commenting on a piece in the Telegraph profiling Nasser Muthana, a former British medical student who appeared in an ISIS recruitment video sparking public debate on the issue of foreign fighters travelling to Syria and Iraq:

"Well-educated and affluent, the jihadis show that the catalyst for jihad is a move toward the faith of Islam. Religiosity is the catalyst." 88

For both Geller and Spencer, Islam is presented as being the driving factor behind extremism and violence. This reflects their interpretation of Islam as a political ideology rather than a disparate global religion, and also the essentialism that leaves little or no room for differing interpretations or evolving understanding.

A simplified interpretation of world events into black and white narratives was also present in the more European focused Politically Incorrect. In summarising a video posted by comedian Pat Condell explaining his support for Israel, the article suggests: 
"Everything one needs to know about the Middle East conflict is: The Jews want peace, the Arabs don't because the Arabs hate the Jews for religious reasons and want them dead." 89

Beyond Muslims, the seed site content was even more critical of political and cultural elites. Direct attacks on political leaders were frequent. In an article on the press policy of the Obama White House centred on a supposed "gaffe", a picture of Obama leaning over a "sneeze guard" to order food, the author describes Obama as part of an "overweening political class" and trying hard to look "normal". Although this is not made explicit in the article, this is consistent with the wider counter jihad discourse (and many other contemporary political discourses) that presents political leaders as out of touch. This position is further hardened in an article posted on Brussels Journal examining the propagation of the idea that "violence never solves anything". This maxim is seen as being perpetuated by powerful and shadowy "elites":

"The claim tends to come from a closed circle of self-confirming elites. The network of the privileged operates in a cell that protects it from contamination by rational critique.", 91

Also evident was hostility towards other figures from civic society such as media pundits that were seen to disagree with counter jihad positions. Geller, for example, rounds on the author of an article in the Huffington Post attacking the practices of her organisation - American Freedom Defense Initiative (AFDI). The author - Rabbi Rachel Gartner - is accused of being the "bane of Jewish existence: the "self-loathing Jew", 92 Similarly, Spencer, in response to a Mail Online article attacks the claims made by Andreas Krieg an academic at King's College London using inverted commas as a tool to question his credentials. He also asserts the position "I'd love to debate Andreas Krieg about this question. But I am sure that he would refuse to do so."93 
Also prevalent in the texts harvested from the seed sites are ideas around the mainstream media. For CJN advocates the mainstream media are inherently untrustworthy. Spencer asks why papers such as the Mail "rush to exonerate Islam of all responsibility for the evermounting number of atrocities done in its name...", also referring to the story he is critiquing as "palpable nonsense" and describing the Daily Mail as "ever-witless". 94 Returning to Obama's food related gaffe, Gates of Vienna creates a story in which the US President can be portrayed as both venal and controlling whilst simultaneously falling out with a press that was previously in awe of him:

“This increasingly disconnected administration doesn't seem to understand the extent to which the MSM [mainstream media] sold its soul to sell him. No matter what they did, it wasn't enough. No one could ever do enough for His Majesty President Obama. 24/7 fawning was simply too little. "95

In addition to the seed sites, a number of sites captured in the hyperlink analysis could comfortably fit within the counter jihad nebula. For example The Religion of Peace is dominated by coverage of Islam which it argues is "one really messed up religion." The home page of the site features a "weekly jihad report" in which the number of "jihad attacks" and "Allah Akbars" (suicide attacks) is recorded. ${ }^{96}$

\section{The CJN and the Media}

The critical treatment of the media by the core CJN sites identified above is perhaps somewhat contradictory given the extent to which CJN articles are based around reproducing media material. Adding to this, the CJN also has a propensity to link to other media sites, either directly to specific articles, or to entire sites. In the case of the Wall Street Journal the links were to an opinion piece from 2011 written by the founder and leader of the Dutch Party for Freedom, Geert Wilders. Wilders is a noted supporter of the of the counter jihad scene. ${ }^{97}$ A further specific mainstream media article comes from the BBC. Posted on 10th 
October 2012, this piece describes the finding of a Pew research report into the religious habits of US citizens. It found that Protestantism was no longer the majority religion and that the numbers of people without religious affiliation was rising. ${ }^{98}$ On both occasions, the mainstream media stories have gone some way to supporting the counter jihad discourse, either explicitly in the case of the opinion written directly by Wilders in the Wall Street Journal, or indirectly in the case of the BBC.

In addition to specific stories from major national press outlets, a further group of partisan media sites such as Breibart, Powerline and National Review were present in the captured network. These sites share a noticeably different approach in tone, content and design than national press instruments such as the Wall Street Journal or the $B B C$, and the fact that CJN sites link to home pages rather than specific stories on these sites indicates a level of comfort with the discourse within. Those editing the CJN core sites are evidently not concerned that these sites will significantly challenge their orthodoxy by presenting a contrasting perspective. This is further confirmed by some of the explicit relationships between CJN authors and this type of site. For instance, Pamela Geller is an active contributor to Breibart. Some articles supported the counter jihad discourse, but not explicitly and very often in a moderated form. For example, texts collected from Breibart all focus on the Obama administration's record on the US-Mexican border, which is presented as being in a state of crisis. Obama is accused of pushing the limit of his powers, through the reporting of a letter written by a Republican member of Congress. ${ }^{99}$ Other stories on the same topic then go on to reinforce the perception that a spike in arrivals is being driven by misconceptions of the US immigration system caused by the administrations Deferred Action for Childhood Arrivals programme. Again, this programme is reported as being "unilaterally enacted" by the administration. ${ }^{100}$ This fits closely with the anti-elitist rhetoric of the CJN, not because the Obama administration is seen as soft on terrorism, but because it is on the wrong side of the 
issue and acting against the common good, an undescribed strong border policy. Equally, National Review's coverage of Hilary Clinton's personal wealth attempts to portray the Clinton's behaviour as being at odds with the "common man". ${ }^{101}$ Furthermore, Clinton's money is differentiated from that of Republican Presidential Candidate Mitt Romney by virtue of being gained through speaking fees and book advances as opposed to "creating jobs, building wealth and expanding the US economy." Again, this maintains an anti-elite line, but a partisan one.

This pattern persists on the occasions that partisan media did cover terrorism and security related issues. For example, Hot Air covered a report released by the Rand Corporation in which analysis of classified and unclassified documents pointed towards an increase in the number of jihadist groups, fundamentalist fighters and attacks carried out by "Al-Qaeda Affiliates" and a supposed reluctance to deal with these issues by the administration. ${ }^{102}$ While both these arguments are orientated towards a counter jihad discourse, highlighting the security threat posed by Islamic fundamentalist terrorism and the apparent failure of the administration, on both counts the coverage is relatively muted compared with that of the CJN seed sites. For example, the article formulates the threat as coming from specific terrorist groups as opposed to either Muslims or Islam as a whole. Equally, whilst appearing to draw attention to the Obama administration's failure to end the war on terror, the article does go on to acknowledge that:

"As reluctant as the present administration may be to agree with Jones [the report's author], they appear to recognize the pressing nature of the threat to national security posed by the proliferation of jihadist groups." 103

Although some articles can be read as partly supportive of the counter jihad narrative, much of the content of alternative news media sites can be viewed as being part of a more mainstream conservative, in particular US conservative, discourse. 
Also present in the network are several individual figures that are difficult to include in the counter jihad nebula specifically, but fit with a more conservative or hawkish discourse that may be evident on partisan news sites. These figures include the academic Daniel Pipes, a noted critic of Islam who himself has been criticised by other academics for his position. ${ }^{104}$ Pipes is difficult to group with other elements of the counter jihad, as he maintains a more moderate and nuanced position. Although very much concerned with security questions and the potential threat of Islamic fundamentalist terrorism, in an article about the gains made in Iraq by the Islamic group ISIS in summer 2014 Pipes maintains that:

"Thanks to the ferocious reputation ISIS has established in its capital city of Raqqa, Syria, and elsewhere, an estimated quarter of Mosul's population of almost two million has fled. The current round of ISIS brutality will newly render Islamism obnoxious to millions more Muslims.", 105

Pipes goes on to reference several counter jihad tropes such as criticism of political leadership, castigating both Republican and Democratic parties for their failures, authorising the invasion of Iraq and believing that the death of Osama bin Laden put an end to the "war on terror" respectively. Despite this, Pipes' overall discourse does not tessellate perfectly with that of the counter jihad nebula as a whole.

\section{Noise}

Finally, a number of sites could not be grouped easily with others. Some were humour and satire-based sites often with a conservative edge. For example, The People's Cube published an article describing the decision of the Governor of California - Democrat Jerry Brown - to change the name of the state to "Caliphornia" and to describe himself as "Caliph". Brown is quoted as saying: 
"To honor and support the founding of the new, thriving Caliphate, and because we love all religions except Christianity, we will now follow Sharia law. "106

The article is obviously satire, but the post also replicates almost exactly the central concern of wider counter jihad discourse, a threatened Islamic takeover with the consent of weak leaders. In addition, Dry Bones is a daily comic that has been produced since 1973 . The content reflects a critical view of European and US attitudes towards Israel based on current events - for example one cartoon presents the Middle East as a "sea of Arabs that are trying to kill each other."107

In addition to satire, the network included a number of smaller blogs reflecting more personal perspectives on world affairs. Often these also reflected a conservative perspective but not always one expressly dominated by the counter jihad viewpoint. Examples include No Pasaran, seemingly the blog of an expat US citizens living in France, and the German centric blog Editrix Roncesvalles. Finally the network also included articles apparently unrelated to politics such as an article from The Atlantic: Why Songs Get Stuck in Your Head. ${ }^{108}$ Hyperlink data is by definition noisy as web crawlers make no distinction between the links they crawl, and so even throwaway or casual links are captured. Although insisting on two in links has reduced the presence of seemingly extraneous links, those that have remained serve as a reminder that despite the seemingly narrow focus of the CJN core sites identified here, they are also capable of engaging with lines of thought outside of their central discourse.

\section{Conclusions}

This analysis is not comprehensive or all encompassing. The choice of seed sites and the limitations of web crawlers means that the network identified above is only a slice of a larger interconnected group of counter jihad thinkers, related media and other sites. The limitation of analysis to only three texts dated at the time of the web crawl further reduces this to a snapshot within a snapshot. In addition, available space means that only a tiny proportion of 
the remaining texts can be considered here, and even then only in the form of brief examples. The CJN and related media (re)produces so much material so quickly that it is the work of years to capture and analyse it. Despite these limitations, this analysis has hopefully done much to improve our understanding of counter jihad discourse online and highlighted the connectedness of what is easy to assume are a relatively self-contained fringe group of activists.

Building on previous analysis, including the work of Digital Methods Initiative, this study has attempted to consider the online counter jihad - the counter jihad nebula - as a subject in itself rather than as background noise to the more visible actions of counter jihad inspired terrorists, street movements and political parties. ${ }^{109}$ While these groups certainly present pressing policy problems for civil society, the wider ideology of the counter jihad scene is being crafted and maintained, in large part, online though the CJN. The combination of hyperlink and discourse analysis used here has offered a unique insight into not only the composition of the CJN, but also the nature of its discourse and how different elements of the network embrace different narratives or borrow from one another in creating discourse.

Analysis of seed site texts reveals a discourse consistent with the current academic understanding of the counter jihad scene. The CJN shares an essentialist view of Islam in which all Muslims are engaged in hostile action or should be treated as such. It is profoundly distrustful of political and cultural elites and it understands itself primarily in cultural and religious rather than nationalistic or racial terms. In addition, the CJN maintains fierce support for Israel and the status of the Jewish community. More conflicted is the CJN's relationship with the media. Many of the articles included in this analysis view the mainstream press as complicit with political elites and often refer to press coverage in derogatory terms and paint it as covering up the "real truth". Despite this, a great deal of content harvested is based on mainstream press articles. CJN sites often reproduce articles 
they agree with, even going so far as translating those not in English. ${ }^{110}$ Where core CJN sites reproduce articles they disagree with, it is to ridicule or dismiss them, for example Robert Spencer's treatment of the Mail Online article. ${ }^{11}$

In addition to reprinting material on CJN sites, the network has uncovered a considerable number of links to media sites outside of the core CJN sites. Gates of Vienna in particular maintains a regular press round up in which tipsters are encouraged to submit links. These tipsters include prominent counter jihad activist Fjordman. ${ }^{112}$ Very often these links have been to partisan press organs that, if not fully supportive of CJN discourse, are at least unlikely to contradict it. Where links are included to other media, these are carefully selected to carry a reader to a specific article. A major function of the CJN, in addition to ideological curation, seems to be to filter and cherry pick supportive articles from the media whilst ignoring, discrediting or explaining away contradictory ones. The CJN is the unofficial custodian of the counter jihad discourse, supporting it where they can and protecting it from criticism where necessary. If a reader were to stay within the confines of the CJN (by no means something to be taken for granted) they would likely arrive at a world-view significantly different from the one held by other citizens. On the question of discourse, this role is not exactly consistent with the closed echo chamber suggested by Sunstein. ${ }^{113}$ The pattern uncovered is closer to the more open model of the Breivik manifesto, borrowing and patching together a narrative from sometimes surprising sources. ${ }^{114}$ This is also notably supportive of Fekete's and Kundnani's suggestions of a societal blindspot for the impact of governmental security narratives on the legitimacy of the far and extreme right. ${ }^{115}$

In the longer term this initial research on the CJN opens up a number of further research questions. Previous work and the experiences of Andreas Krieg support the connection between various defence leagues, political parties, Breivik and the CJN. ${ }^{116}$ However, this analysis has not done much to reinforce these connections beyond establishing a shared 
discourse. None of these groups manifested in the network uncovered here, nor were they identified in texts collected. A more comprehensive analysis, or a different set of seed sites may do more to further establish these connections. The inclusion of so much mainstream and partisan media in the network also raises further questions about the degree to which media reporting is at least vulnerable to appropriation by counter jihadists. It is important to differentiate between the hard-core conspiratorial elements within the CJN and the sources they choose to link to. A tacit endorsement by Robert Spencer is a long way from full ideological affinity and should not be taken as such. Mainstream and partisan media sites may not fully endorse the essentialist view of Islam or the CJN's sense of Western decline, but at times they do little to contradict it either. For all the connections drawn between the CJN and the actions of the wider counter jihad scene, it seems unlikely that a typical EDL foot soldier will be a dedicated reader of any part of the CJN. It is far more likely, however, that they will have viewed material in the mainstream media that does not challenge the overall discourse presented by the EDL. Distinguishing between these two narratives requires a level of nuance, sophistication and media literacy that is unlikely to be found in day-to-day public discourse. The CJN itself may be more a tool for opinion leaders than foot soldiers. ${ }^{117}$ Finally, explicit references to the Eurabia conspiracy theory has been suspiciously absent from this analysis. Again, we must understand the limitations of this analysis in both time and scope, but the use of more generalised anti-elite and anti-Muslim sentiment in place of conspiracy is perhaps an indication that on a day-to-day level, the influence of Eurabia can be overestimated. Whilst the conspiracy may serve an important ideological function, for the "typical" counter jihad supporter it may well be of less relevance than more generalised fears based on cultural nationalism, security concerns and a fear of the other stoked by at times sensationalist and media reporting. 
FIGURE ONE: Links between seed sites

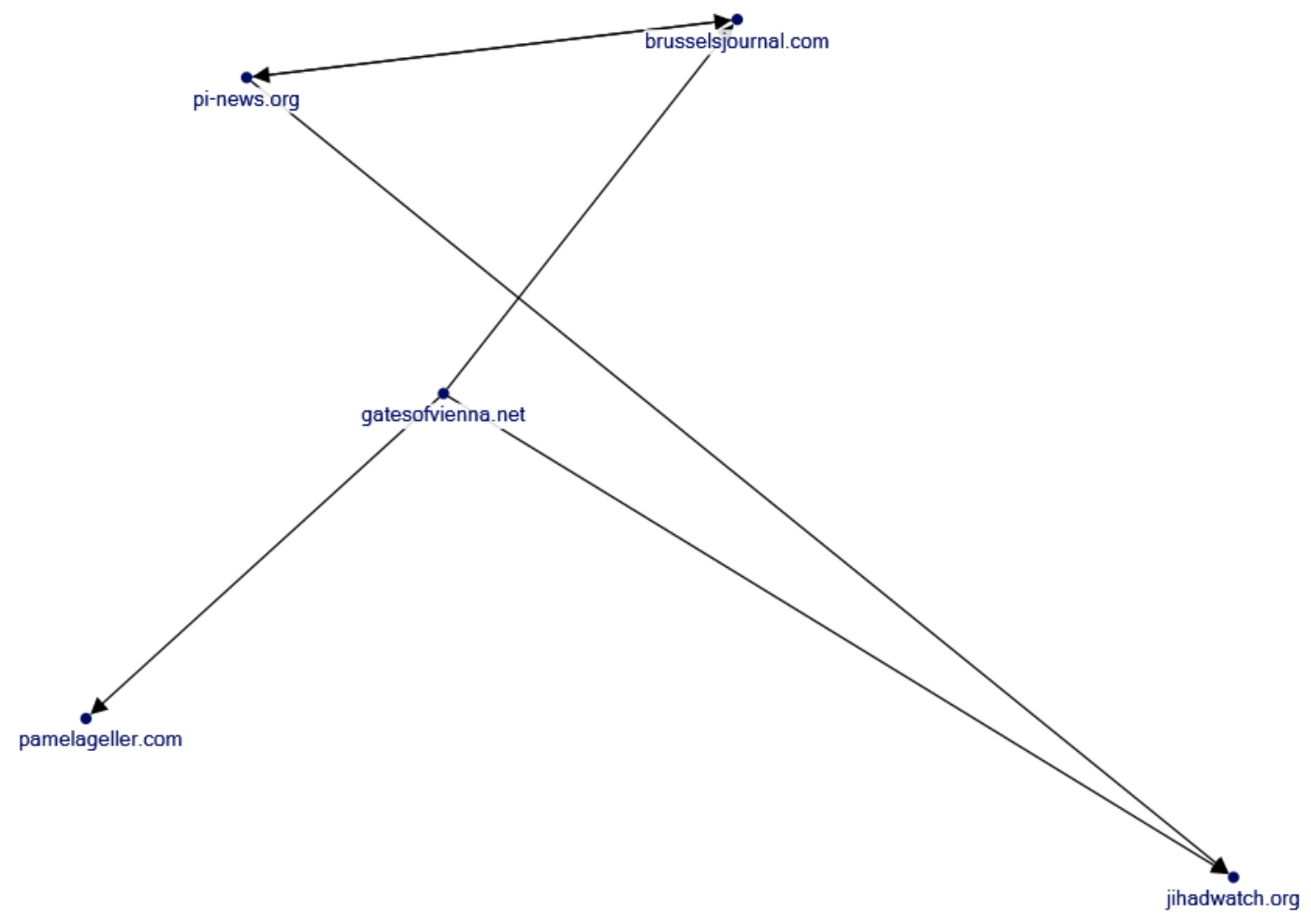

Created with NodeXL (http:J/nodexl.codeplex.com) 
FIGURE TWO: Links between seed sites and sites with more than two in links

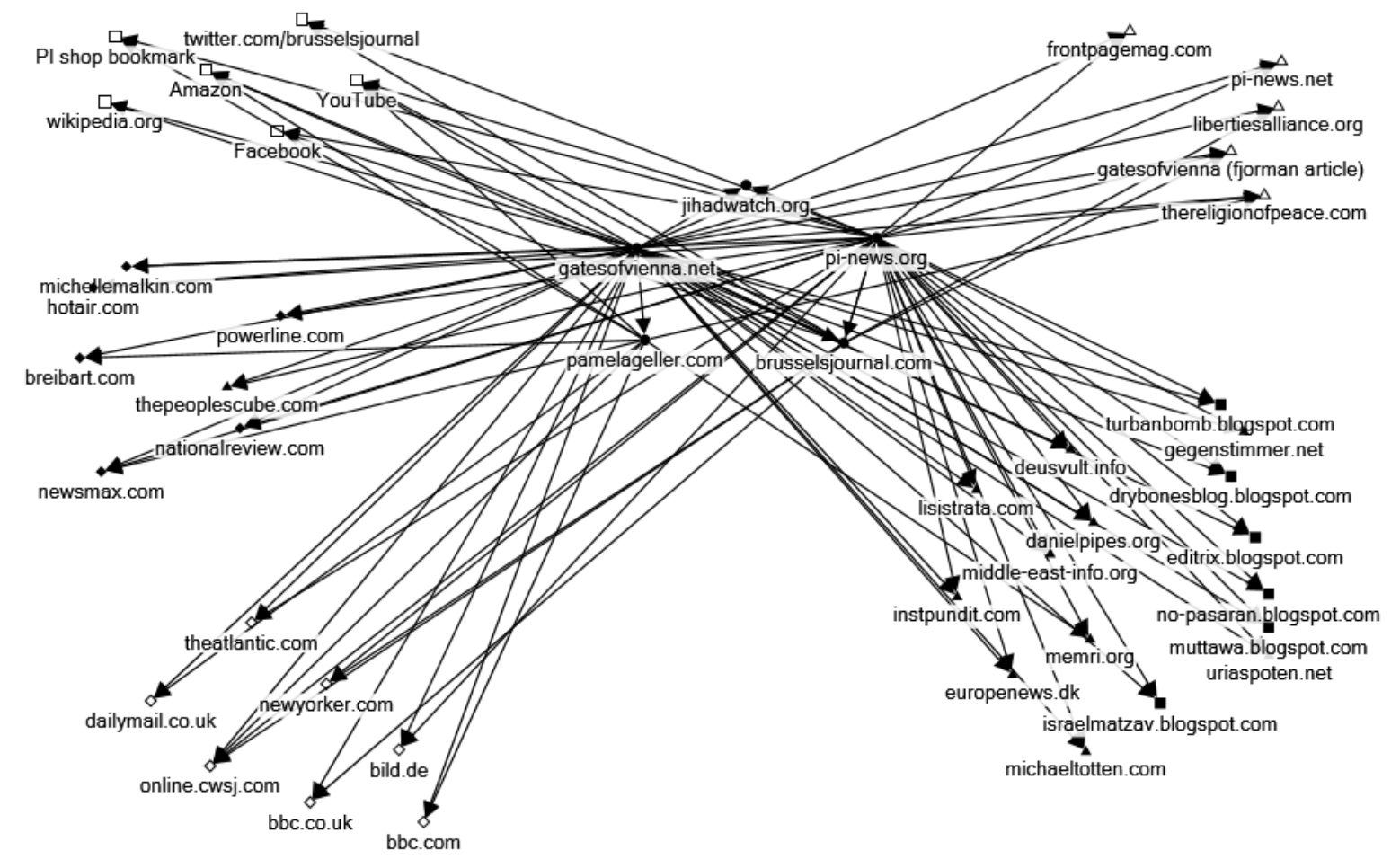

Created with NodeXL (http://nodexl.codeplex.com) 


\section{Notes}

\footnotetext{
${ }^{1}$ Matthew Goodwin, The Roots of Extremism: The English Defence League and the Counter-Jihad Challenge. (London: Chatham House, 2013), 3.

${ }^{2}$ Matthew Feldman, “Comparative Lone Wolf Terrorism: Toward a Heuristic Definition.” Democracy and Security 9, no. 3 (2013): 270-86.

${ }^{3}$ Sindre Bangstad, "Eurabia Comes to Norway." Islam and Christian-Muslim Relations 24, no. 3 (2013): 36991.

${ }^{4}$ Gavan Titley, "They Called a War, and Someone Came: The Communicative Politics of Breivik's Ideoscape." Nordic Journal of Migration Research 3, no. 4 (2013): 216-24; Liz Fekete. "The Muslim Conspiracy Theory and the Oslo Massacre." Race \& Class 53, no. 3 (2011): 30-47; Gavan Titley, "They Called a War, and Someone Came: The Communicative Politics of Breivik's Ideoscape." Nordic Journal of Migration Research 3, no. 4 (2013): 216-24; Jacob Ravndal, Anders Behring Breivik's use of the Internet and Social Media Journal Exit-Deutschland 2 (2013): 172 - 185; Toby Archer, "Breivik's Mindset: The Counterjihad and the New Transatlantic Anti-Muslim Right" in Extreme Right Wing Violence and Political Terrorism eds Max Taylor, PM Currie and Donald Holbrook (London: Bloomsbury, 2013): 149-169; Mattias Gardnell. "Crusader Dreams: Oslo 22/7, Islamophobia and the Quest for a Monocultural Europe." Terrorism and Political Violence 26, no 1
} (2014): 129-155.

${ }^{5}$ Paul Jackson, “The License to Hate: Peder Jensen's Fascist Rhetoric in Anders Breivik's Manifesto 2083: A European Declaration of Independence." Democracy and Security 9, no. 3 (2013): 247-69.

${ }^{6}$ Jacob Ravndal, Anders Behring Breivik's use of the Internet and Social Media Journal Exit-Deutschland 2 (2013): $172-185$

7 James Treadwell, and Jon Garland, "Masculinity, Marginalization and Violence: A Case Study of the English Defence League.” British Journal of Criminology 51, no. 4 (2011): 621-34; Paul Jackson and Matthew Feldman. "The EDL: Britain's 'New Far Right' Social Movement." Northampton: The University of Northampton (2011); Treadwell, James. "The English Defence League and the Counter Jihad." Criminal Justice Matters 93, no. 1 (2013): 8-9; Matthew Goodwin, The Roots of Extremism: The English Defence League and the Counter-Jihad Challenge. (London: Chatham House, 2013).

${ }^{8}$ Joel Busher, "Grassroots Activism in the English Defence League: Discourse and Public (Dis)order" in Extreme Right Wing Violence and Political Terrorism eds Max Taylor, PM Currie and Donald Holbrook (London: Bloomsbury, 2013): 65-85

${ }^{9}$ Alexander Meleagrou-Hitchens and Hans Brun, A Neo-Nationalist Network: The English Defence League and Europe's Counter-Jihad Movement, (London: ICSR, 2013): 22

${ }^{10}$ Nick Denes, "“Welcome to the Counterjihad': Uncivil Networks and the Narration of European Public Spheres." Journal of Civil Society 8, no. 3 (2012): 295

11 "Breivik's Swamp: Was the Oslo killer radicalized by what he read online?", accessed April 9, 2014, http://www.foreignpolicy.com/articles/2011/07/25/breivik s swamp, see also, "Killings in Norway Spotlight Anti-Muslim Thought in US", accessed January 13, 2015, http://www.nytimes.com/2011/07/25/us/25debate.html?pagewanted=all\& $\mathrm{r}=0$.

${ }^{12}$ Alexander Meleagrou-Hitchens and Hans Brun, A Neo-Nationalist Network: The English Defence League and Europe's Counter-Jihad Movement. (London: ICSR, 2013): 1.

${ }^{13}$ Matthew Goodwin, The Roots of Extremism: The English Defence League and the Counter-Jihad Challenge. (London: Chatham House, 2013): 3; Alexander Meleagrou-Hitchens and Hans Brun, A Neo-Nationalist Network: The English Defence League and Europe's Counter-Jihad Movement. (London: ICSR, 2013).

${ }^{14}$ Paul Jackson and Matthew Feldman. "The EDL: Britain's 'New Far Right' Social Movement." (Northampton: The University of Northampton, 2011).

${ }^{15}$ José Zúquete, “The European Extreme-Right and Islam: New Directions?” Journal of Political Ideologies 13, no. 3 (2008): 321-44.

${ }^{16}$ Arun Kundnani, Blind Spot? Security Narratives and Far-Right Violence in Europe. (The Hague: ICCT Research Paper, 2012): 5

${ }^{17}$ Matthew Goodwin, The Roots of Extremism: The English Defence League and the Counter-Jihad Challenge. (London: Chatham House, 2013). One example of this may be the recently founded LibertyGB in the UK, a self-described 'counter-jihad' political party. See also Joel Busher's analysis of likely future trajectories for the EDL Joel Busher, "Anti-Muslim Populism in the UK: the Development of the English Defence League," in The Changing Faces of Populism: Systemic Challenges in Europe and the US, eds Hedwig Giusto, David Kitching and Stefano Rizzo (Brussels: Foundation for European Progressive Studies, undated).

${ }^{18}$ Steven Boegborn, Matthew Elworthy, Joseph Jackson, Charly Landman and Kieran Lewis, "Reading the Counter Jihad Discourse". Accessed May 11, 2015, https://www.digitalmethods.net/CounterJihadism/ProjectGroup10 
; Joel Busher, "Grassroots Activism in the English Defence League: Discourse and Public (Dis)order" in Extreme Right Wing Violence and Political Terrorism eds Max Taylor, PM Currie and Donald Holbrook (London: Bloomsbury, 2013): 65-85

${ }^{19}$ Alexander Meleagrou-Hitchens and Hans Brun, A Neo-Nationalist Network: The English Defence League and Europe's Counter-Jihad Movement. (London: ICSR, 2013): 41.

${ }^{20}$ Hans-Georg Betz, "A Distant Mirror: Nineteenth-Century Populism, Nativism, and Contemporary Right-

Wing Radical Politics.” Democracy and Security 9, no. 3 (2013): 200-220.

${ }^{21}$ Matt Carr, "You Are Now Entering Eurabia." Race \& Class 48, no. 1 (2006): 1-22.

${ }^{22}$ Matt Carr, "You Are Now Entering Eurabia." Race \& Class 48, no. 1 (2006): 1-22. Melanie Philips is currently a columnist for the UK daily newspaper the Daily Mail and Mark Steyn is the former theatre critic for another daily newspaper the Independent.

23 "Eurabia?", accessed April 9, 2014, http://www.nytimes.com/2004/04/04/magazine/04WWLN.html.

${ }^{24}$ Matt Carr, "You Are Now Entering Eurabia." Race \& Class 48, no. 1 (2006): 1-22.

${ }^{25}$ Liz Fekete. "The Muslim Conspiracy Theory and the Oslo Massacre." Race \& Class 53, no. 3 (2011): 30-47; Gavan Titley, "They Called a War, and Someone Came: The Communicative Politics of Breivik's Ideoscape." Nordic Journal of Migration Research 3, no. 4 (2013): 216-24.

${ }^{26}$ José Zúquete, “The European Extreme-Right and Islam: New Directions?” Journal of Political Ideologies 13, no. 3 (2008): 324.

${ }^{27}$ José Zúquete, “The European Extreme-Right and Islam: New Directions?” Journal of Political Ideologies 13, no. 3 (2008): 321-44.

${ }^{28}$ Arun Kundnani, Blind Spot? Security Narratives and Far-Right Violence in Europe. (The Hague: ICCT Research Paper, 2012): 6.

${ }^{29}$ Nigel Copsey, "Changing Course or Changing Clothes? Reflections on the Ideological Evolution of the British National Party 1999-2006." Patterns of Prejudice 41, no. 1 (2007): 61-82.

${ }^{30}$ Alexander Meleagrou-Hitchens and Hans Brun, A Neo-Nationalist Network: The English Defence League and Europe's Counter-Jihad Movement. (London: ICSR, 2013).

${ }^{31}$ Alexander Meleagrou-Hitchens and Hans Brun. A Neo-Nationalist Network: The English Defence League and Europe's Counter-Jihad Movement. (London: ICSR, 2013); Farid Hafez, "Shifting Borders: Islamophobia as Common Ground for Building Pan-European Right-Wing Unity." Patterns of Prejudice 48, no. 5 (2014): 479_ 99.

32 José Zúquete, “The European Extreme-Right and Islam: New Directions?” Journal of Political Ideologies 13, no. 3 (2008): 321-44.

${ }^{33}$ Ruth Wodak and Majid KhosraviNik, "Dynamics of Discourse and Politics in Right-Wing Populism in Europe and Beyond: An Introduction" in Right Wing Populism in Europe: Politics and Discourse, eds. Ruth Wodak, Majid KhosraviNik and Brigitte Mral, (London: Bloomsbury, 2013): XIX.

${ }^{34}$ Carle, Robert. "Anders Breivik and the Death of Free Speech in Norway.” Society 50, no. 4 (2013): 397).

${ }^{35}$ James Treadwell and Jon Garland, "Masculinity, Marginalization and Violence: A Case Study of the English Defence League.” British Journal of Criminology 51, no. 4 (2011): 623.

${ }^{36}$ Liz Fekete, "The Muslim Conspiracy Theory and the Oslo Massacre." Race \& Class 53, no. 3 (2011): 33; ; Nathan Lean. The Islamophobia Industry: How the Right Manufactures Fear of Muslims. London: Pluto Press (2012): 11; Hans-Georg Betz, "A Distant Mirror: Nineteenth-Century Populism, Nativism, and Contemporary Right-Wing Radical Politics.” Democracy and Security 9, no. 3 (2013): 200-220; Farid Hafez, "Shifting Borders: Islamophobia as Common Ground for Building Pan-European Right-Wing Unity." Patterns of Prejudice 48, no. 5 (2014): 498.

${ }^{37}$ José Zúquete, “The European Extreme-Right and Islam: New Directions?” Journal of Political Ideologies 13, no. 3 (2008): 321-44; Arun Kundnani, Blind Spot? Security Narratives and Far-Right Violence in Europe. (The Hague: ICCT Research Paper, June 2012).

${ }^{38}$ Gavan Titley, “They Called a War, and Someone Came: The Communicative Politics of Breivik's Ideoscape." Nordic Journal of Migration Research 3, no. 4 (2013): 218).

${ }^{39}$ Gavan Titley, "They Called a War, and Someone Came: The Communicative Politics of Breivik's Ideoscape." Nordic Journal of Migration Research 3, no. 4 (2013): 218; Alexander Meleagrou-Hitchens and Hans Brun, A Neo-Nationalist Network: The English Defence League and Europe's Counter-Jihad Movement. (London: ICSR, 2013): 42.

${ }^{40}$ Liz Fekete,"The Muslim Conspiracy Theory and the Oslo Massacre.” Race \& Class 53, no. 3 (2011): 35-36.

${ }^{41}$ Paul Jackson and Matthew Feldman. "The EDL: Britain's 'New Far Right' Social Movement." (Northampton: The University of Northampton, 2011); Hans-Georg Betz, (2013) 'Mosques, Minarets, Burquas and Other Essential Threats: The Populist Right's Campaign against Islam in Western Europe' in Right Wing Populism in Europe: Politics and Discourse, eds. Ruth Wodak, Majid KhosraviNik and Brigitte Mral, (London: Bloomsbury, 2013); Farid Hafez, "Shifting Borders: Islamophobia as Common Ground for Building PanEuropean Right-Wing Unity.” Patterns of Prejudice 48, no. 5 (2014): 479-99. 
${ }^{42}$ Lorraine Sheridan, "Islamophobia Pre- and Post-September 11th, 2001." Journal of Interpersonal Violence 21, no. 3 (2006):324-385; Robert Lambert, "Anti-Muslim Violence in the UK: Extremist Nationalist Involvement and Influence" " in Extreme Right Wing Violence and Political Terrorism eds Max Taylor, PM Currie and Donald Holbrook (London: Bloomsbury, 2013): 31-65.

${ }^{43}$ Liz Fekete, "Anti-Muslim Racism and the European Security State." Race \& Class 46, no. 1 (2004): 3-29; Arun Kundnani, Blind Spot? Security Narratives and Far-Right Violence in Europe. (The Hague: ICCT Research Paper, 2012).

${ }^{44}$ Liz Fekete, “The Muslim Conspiracy Theory and the Oslo Massacre.” Race \& Class 53, no. 3 (2011): 39; Hans-Georg Betz, "Mosques, Minarets, Burquas and Other Essential Threats: The Populist Right's Campaign against Islam in Western Europe" in Right Wing Populism in Europe: Politics and Discourse, eds. Ruth Wodak, Majid KhosraviNik and Brigitte Mral, (London: Bloomsbury, 2013): 83.

${ }^{45}$ James Treadwell and Jon Garland, "Masculinity, Marginalization and Violence: A Case Study of the English Defence League." British Journal of Criminology 51, no. 4 (2011): 621-34.

${ }^{46}$ James Treadwell and Jon Garland, "Masculinity, Marginalization and Violence: A Case Study of the English Defence League." British Journal of Criminology 51, no. 4 (2011): 626.

${ }^{47}$ Alexander Meleagrou-Hitchens and Hans Brun, A Neo-Nationalist Network: The English Defence League and Europe's Counter-Jihad Movement. (London: ICSR, 2013): 22

${ }^{48}$ Liz Fekete, "The Muslim Conspiracy Theory and the Oslo Massacre." Race \& Class 53, no. 3 (2011): 30-47; Alexander Meleagrou-Hitchens and Hans Brun, A Neo-Nationalist Network: The English Defence League and Europe's Counter-Jihad Movement. (London: ICSR, 2013): 42

${ }^{49}$ Alexander Meleagrou-Hitchens and Hans Brun, A Neo-Nationalist Network: The English Defence League and Europe's Counter-Jihad Movement. (London: ICSR, 2013): 42

${ }^{50}$ Liz Fekete. "Anti-Muslim Racism and the European Security State." Race \& Class 46, no. 1 (2004): 4-29.

${ }^{51}$ Titley, Gavan. "They Called a War, and Someone Came: The Communicative Politics of Breivik's Ideoscape." Nordic Journal of Migration Research 3, no. 4 (2013): 218.

${ }_{52}$ Arun Kundnani, Blind Spot? Security Narratives and Far-Right Violence in Europe. (The Hague: ICCT Research Paper, 2012): 6.

${ }^{53}$ Matt Carr, "You Are Now Entering Eurabia." Race \& Class 48, no. 1 (2006): 1-22; Sindre Bangstad, "Eurabia Comes to Norway." Islam and Christian-Muslim Relations 24, no. 3 (2013): 369-91. Toby Archer, "Breivik's Mindset: The Counterjihad and the New Transatlantic Anti-Muslim Right" in Extreme Right Wing Violence and Political Terrorism eds Max Taylor, PM Currie and Donald Holbrook (London: Bloomsbury, 2013): 149-169.

${ }_{54}^{5}$ Bat Ye'or, Eurabia: The Euro-Arab Axis (Maryland: Fairleigh Dickenson Press, 2005).

${ }^{55}$ Rory Miller, "Review of Eurabia: The Euro-Arab Axis by Bat Y'eor." Middle Eastern Studies 42, no. 4

(2006): 682-85; Sindre Bangstad, "Eurabia Comes to Norway." Islam and Christian-Muslim Relations 24, no. 3 (2013): 369-91.

${ }^{56}$ Alexander Meleagrou-Hitchens and Hans Brun, A Neo-Nationalist Network: The English Defence League and Europe's Counter-Jihad Movement. (London: ICSR, 2013): 3.

${ }^{57}$ Toby Archer, "Breivik's Mindset: The Counterjihad and the New Transatlantic Anti-Muslim Right" in

Extreme Right Wing Violence and Political Terrorism eds Max Taylor, PM Currie and Donald Holbrook (London: Bloomsbury, 2013): 149-169.

${ }^{58}$ Alexander Meleagrou-Hitchens and Hans Brun, A Neo-Nationalist Network: The English Defence League and Europe's Counter-Jihad Movement. (London: ICSR, 2013): 23.

${ }^{59}$ Arun Kundnani, Blind Spot? Security Narratives and Far-Right Violence in Europe. (The Hague: ICCT Research Paper, 2012).

${ }^{60}$ Arun Kundnani, Blind Spot? Security Narratives and Far-Right Violence in Europe (The Hague: ICCT Research Paper, 2012): 4.

${ }^{61}$ Christopher Allen, and Jorgen Nielsen. Summary Report on Islamophobia in the EU after 11 September 2001. (Birmingham: Centre for the Study of Islam and Christian-Muslim Relations, 2002); Sheridan, Lorraine P.

"Islamophobia Pre- and Post-September 11th, 2001." Journal of Interpersonal Violence 21, no. 3 (2006): 31736.

${ }^{62}$ Matt Carr, "You Are Now Entering Eurabia." Race \& Class 48, no. 1 (2006): 1-22.

63 "Anders Breivik's spider web of hate", accessed on April 9, 2014, http://www.theguardian.com/commentisfree/2011/sep/07/anders-breivik-hate-manifesto.

${ }^{64}$ Paul Jackson, "The License to Hate: Peder Jensen's Fascist Rhetoric in Anders Breivik's Manifesto 2083: A European Declaration of Independence." Democracy and Security 9, no. 3 (2013): 247-269.

${ }^{65}$ Jacob Ravndal, Anders Behring Breivik's use of the Internet and Social Media Journal Exit-Deutschland 2 (2013): 172 - 185; Mattias Gardnell. "Crusader Dreams: Oslo 22/7, Islamophobia and the Quest for a Monocultural Europe.’Terrorism and Political Violence 26, no 1 (2014): 129-155; Paul Jackson, "The License 
to Hate: Peder Jensen's Fascist Rhetoric in Anders Breivik's Manifesto 2083: A European Declaration of Independence." Democracy and Security 9, no. 3 (2013): 247-269.

66 "What does the Internet add? Studying extremism and counter-jihadism online", accessed on May 11, 2015, https://www.digitalmethods.net/CounterJihadism/WebHome.

${ }^{67}$ See the work of project group two, "Online Activity of the English Defence League”, accessed May 11, 2015, https://www.digitalmethods.net/CounterJihadism/ProjectGroup2.

${ }^{68}$ See the work of project group 5, "My Enemy’s Enemy’s My Friend: Mapping \& Comparing Counter-Jihad and Pro-Israel Support on Social Networks" accessed May 11, 2015,

https://www.digitalmethods.net/CounterJihadism/ProjectGroup5.

${ }^{69}$ See project group 10 "Reading the Counter-Jihad Discourse" accessed May 11, 2015,

https://www.digitalmethods.net/CounterJihadism/ProjectGroup10.

${ }^{70}$ Michael Whine, "Cyberspace-A New Medium for Communication, Command, and Control by Extremists." Studies in Conflict \& Terrorism 22, no. 3 (1999): 231-45; Virchow, Fabian, "The Groupuscularization of NeoNazism in Germany: The Case of the Aktionsbüro Norddeutschland.” Patterns of Prejudice 38, no. 1 (2004): 56-70; Caiani, Manuela, and Claudius Wagemann, "Online Networks of the Italian and German Extreme Right." Information, Communication \& Society 12, no. 1 (2009): 66-109.

${ }^{71}$ Clare Bratten, “Online Zealotry: La France Du Peuple Virtuel.” New Media \& Society 7, no. 4 (2005): $517-$ 532; Michael Whine, "Cyberspace-A New Medium for Communication, Command, and Control by

Extremists." Studies in Conflict \& Terrorism 22, no. 3 (1999): 231-45.

${ }^{72}$ Nigel Jackson, and Darren Lilleker, "Building an Architecture of Participation? Political Parties and Web 2.0

in Britain." Journal of Information Technology \& Politics 6, no. 3-4 (2009): 232-50.

${ }^{73}$ Nicholas Negroponte, Being Digital (New York: Vintage Books, 1995); Cas Sunstein, Republic 2.0

(Princeton: Princeton University Press, 2007)

${ }^{74}$ Nathan Lean, The Islamophobia Industry: How the Right Manufactures Fear of Muslims (London: Pluto Press, 2012)

${ }^{75}$ Cas Sunstein, Republic 2.0 (Princeton: Princeton University Press, 2007).

${ }^{76}$ Cas Sunstein, Republic 2.0 (Princeton: Princeton University Press, 2007).

${ }^{77}$ Jacob Ravndal, Anders Behring Breivik's use of the Internet and Social Media, Journal Exit-Deutschland 2 (2013): $172-185$.

${ }^{78}$ Arun Kundnani, Blind Spot? Security Narratives and Far-Right Violence in Europe. (The Hague: ICCT Research Paper, 2012).

${ }^{79}$ Arun Kundnani, Blind Spot? Security Narratives and Far-Right Violence in Europe. (The Hague: ICCT Research Paper, 2012): 5.

${ }^{80}$ Liz Fekete, “Anti-Muslim Racism and the European Security State.” Race \& Class 46, no. 1 (2004): 3-29.

${ }^{81}$ Toby Archer, "Breivik's Mindset: The Counterjihad and the New Transatlantic Anti-Muslim Right" in

Extreme Right Wing Violence and Political Terrorism eds Max Taylor, PM Currie and Donald Holbrook (London: Bloomsbury, 2013): 149-169.

${ }^{82}$ Matt Carr, "You Are Now Entering Eurabia." Race \& Class 48, no. 1 (2006): 1-22; “Anders Breivik's spider web of hate", accessed on April 9, 2014, http:/www.theguardian.com/commentisfree/2011/sep/07/andersbreivik-hate-manifesto.

83 John Scott, Social Network Analysis: A Handbook (London: Sage, 1999): 2

${ }^{84}$ Michael Foucault (1972) quoted in Anders Hansen and David Machin, Media and Communication Research Methods: An Introduction (London: Palgrave, 2013): 117

${ }^{85}$ In some cases the dates of posts were not noted by the authors (see for example Breibart). In these cases, the three most recent stories were collected from the date of data collection - July 15, 2014.

${ }^{86}$ In order to check this a second web crawl was performed in which jihadwatch again failed to produce any outgoing links. This can be achieved by using the 'robots exclusion standard,' a small piece of code that prevents automated services such as VOSON from cataloguing information. However, including this would also likely have an impact on the ability of search engines and other tools to catalogue a site. Jihadwatch is returned by search engines such as Google. A further explanation may be the design of the site itself is somehow limiting the use of VOSON.

87 “"Middle East Security Analyst': The Rise of Global Jihad 'Has Nothing to do with Islam'”, accessed January 13, 2015, http://www.jihadwatch.org/2014/06/middle-east-security-analyst-rise-of-global-jihad-has-nothing-todo-with-islam.

88 "Muslim Medical Student is 'Happy' Recruit for Jihad”, accessed January 13, 2015, http://pamelageller.com/2014/06/pamela-geller-wnd-column-muslim-medical-student-happy-recruit-jihad.html/

89 "Pat Condell Why I Support Israel”, accessed on January 13, 2015, http://www.pi-news.org/2014/06/patcondell-why-i-support-israel/. Pat Condell is a former stand-up comic and now an online critic of religion. His website is available here: http://www.patcondell.net/. 
90 "Noblesse Oblige Fingers the Fast Food", accessed on January 13, 2015, http://gatesofvienna.net/2014/06/noblesse-oblige-fingers-the-fast-food/.

91 "A Lie that can be Sold as the Truth is Poison" accessed on January 13, 2015, http://www.brusselsjournal.com/node/5138.

92،"Pamela Geller, Breitbart: An Antidote for the Self-Loathing Jew" accessed January 13, 2015, http://pamelageller.com/2014/06/pamela-geller-breitbart-antidote-self-loathing-jew.html/.

93 “'Middle East Security Analyst': The Rise of Global Jihad 'Has Nothing to do with Islam'”, accessed January 13, 2015, http://www.jihadwatch.org/2014/06/middle-east-security-analyst-rise-of-global-jihad-has-nothing-todo-with-islam. Email contact with Andreas Krieg reveals that Robert Spencer did try and contact him on the day he published the article but it is not clear if this contact came before or after he published. Spencer's choice of words suggests that he only contacted him after. Andreas Krieg also reports several contacts from self-described EDL affiliated Twitter accounts. Those attempting to contact Andreas Krieg cited Spencer's article as well as other blog posts on a similar theme.

94 “"Middle East Security Analyst': The Rise of Global Jihad 'Has Nothing to do with Islam'”, January 13,

2015, http://www.jihadwatch.org/2014/06/middle-east-security-analyst-rise-of-global-jihad-has-nothing-to-dowith-islam.

95 "Noblesse Oblige Fingers the Fast Food", accessed on January 13, 2015, http://gatesofvienna.net/2014/06/noblesse-oblige-fingers-the-fast-food/. Strikethrough in original.

96 "The Religion of Peace" accessed on January 14, 2015, http://www.thereligionofpeace.com/.

${ }^{97}$ Arun Kundnani, Blind Spot? Security Narratives and Far-Right Violence in Europe. (The Hague: ICCT Research Paper, 2012). The original Wilders article can be found at:

http://www.wsj.com/news/articles/SB10001424052748704409004576146332536459942?mg=reno64wsi\&url=http\%3A\%2F\%2Fonline.wsi.com\%2Farticle\%2FSB1000142405274870440900457614633253645994 2.html

98 "US Protestants No Longer a Majority - Study" accessed on January 13, 2015, http://www.bbc.co.uk/news/world-us-canada-19892837.

99 "Exclusive, Sessions Warns all of Congress: Obama's New Immigration Strategy 'Threatens Foundation of Our Constitutional Republic'”, accessed on January 13, 2015, http://www.breitbart.com/big-

government/2014/07/15/exclusive-sessions-warns-all-of-congress-obama-s-new-immigration-strategy-threatensfoundation-of-our-constitutional-republic/.

100 "Leaked Intel Report: 95\% of Migrants Expected to Receive Amnesty 'Permisos"”, accessed on January 13, 2015, http://cdn.breitbart.com/Big-Government/2014/07/14/Leaked-Intel-Report-219-of-230-MigrantsInterviewed-Expected-to-Receive-Amnesty-Permisos.

101 "Hilary Clinton Earned Millions Speaking to Corporate Executives" accessed on January 13, 2015, http://www.nationalreview.com/article/381253/hillary-clinton-earned-millions-speaking-corporate-executivescelina-durgin.

102 “Al-Qaeda 'decimated?' Study Shows Terror Group's Attacks on the Rise”, accessed on January 13, 2015, http://hotair.com/archives/2014/06/25/al-qaeda-on-the-run-study-shows-terror-groups-attacks-on-the-rise/.

103 “Al-Qaeda 'decimated?' Study Shows Terror Group's Attacks on the Rise”, accessed on January 13, 2015, http://hotair.com/archives/2014/06/25/al-qaeda-on-the-run-study-shows-terror-groups-attacks-on-the-rise/.

${ }^{104}$ Arun Kundnani titled his most recent work The Muslims are Coming as a reference to an article written by Pipes for National Review in 1990. The original text can be found at: http://www.danielpipes.org/198/themuslims-are-coming-the-muslims-are-coming (accessed July 28, 2014).

105 "ISIS Rampages, the Middle East Shakes", accessed on January 13, 2014, http://www.danielpipes.org/14473/isis-iraq-mosul.

106 "Confused Caliph. Governor Declares Himself Caliph, Mandates Sharia Law", accessed on January 13, 2015, http://thepeoplescube.com/peoples-blog/confused-governor-brown-declares-sharia-law-in-california$\mathrm{t} 14159 . \mathrm{html}$.

107 "Israel and the Kurds", accessed on January 13, 2015, http://drybonesblog.blogspot.co.uk/2014/06/israeland-kurds.html.

108 "Why Songs Get Stuck in Your Head", accessed on January 13, 2015,

http://www.theatlantic.com/health/archive/2014/01/why-songs-get-stuck-in-your-head/282997/.

${ }^{109}$ See "What does the Internet add? Studying extremism and counter-jihadism online" accessed May 11, 2015, https://www.digitalmethods.net/CounterJihadism/WebHome.

110 "The Jihad from Germany", accessed on January 13, 205, http://gatesofvienna.net/2014/06/the-jihad-fromgermany/.

111 “"Middle East Security Analyst': The Rise of Global Jihad 'Has Nothing to do with Islam”, accessed January 13, 2015, http://www.jihadwatch.org/2014/06/middle-east-security-analyst-rise-of-global-jihad-hasnothing-to-do-with-islam. 
112 "Gates of Vienna News Feed 6/25/2014", accessed on January 13, 2015, http://gatesofvienna.net/2014/06/gates-of-vienna-news-feed-6252014/.

${ }^{113}$ Cas Sunstein, Republic 2.0 (Princeton: Princeton University Press, 2007).

114 "Anders Breivik's spider web of hate", accessed on January 9, 2015,

http://www.theguardian.com/commentisfree/2011/sep/07/anders-breivik-hate-manifesto.

${ }^{115}$ Kundnani, Arun, Blind Spot? Security Narratives and Far-Right Violence in Europe. (The Hague: ICCT

Research Paper, 2012); Fekete, Liz. "Anti-Muslim Racism and the European Security State." Race \& Class 46, no. 1 (2004): 3-29.

${ }^{116}$ Meleagrou-Hitchens, Alexander, and Hans Brun, A Neo-Nationalist Network: The English Defence League and Europe's Counter-Jihad Movement. (London: ICSR, 2013), and Paul Jackson. "The License to Hate: Peder Jensen's Fascist Rhetoric in Anders Breivik's Manifesto 2083: A European Declaration of Independence." Democracy and Security 9, no. 3 (July 2013)

${ }^{117}$ Elihu Katz and Paul Lazarsfeld, Personal Influence: The Part Played by People in the Flow of Mass Communication. (New York: The Free Press,1955). 